\title{
Chapter 11 Luz Invisible
}

Si en el firmamento poder yo tuviera, esta noche negra lo mismo que un pozo, con un cuchillito de luna lunera, cortaría los hierros de tu calabozo. Si yo fuera reina de la luz del día, del viento y del mar, cordeles de esclava yo me ceñiría por tu libertad.

¡Ay, pena, penita, pena -pena-, pena de mi corazón, que me corre por las venas -penacon la fuerza de un ciclón! Es lo mismo que un nublado de tiniebla y pedernal. Es un potro desbocado que no sabe dónde va. Es un desierto de arena -pena-, es mi gloria en un penal.

¡Ay, penal! ¡Ay, penal! ¡Ay, pena, penita, pena!

Yo no quiero flores, dinero, ni palmas, quiero que me dejen llorar tus pesares y estar a tu vera, cariño del alma, bebiéndome el llanto de tus soleares. Me duelen los ojos de mirar sin verte, reniego de mí, que tienen la culpa de tu mala suerte mis rosas de abril. 
¡Ay, pena, penita, pena -pena-, pena de mi corazón.... ${ }^{1}$

"Luz Invisible" is a copla, or Spanish song, popularized in the 1940s and appropriated by the Franco regime to symbolize the essence of Spanish character. Like the relationship of jazz and blues, coplas are a cousin to flamenco, cante jondo, the guttural, deeply emotional, and emblematic Andalusian music. In the café cantantes of the mid-nineteenth century, singers, musicians, and dancers popularized coplas, elaborating on the rawer, less flowery Flamenco. Coplas, an amalgam of "poetry, narrative, music and theater," appealed to urban middle and upper classes. Their roots go back to the oral tradition of popular poetry during the Middle Ages, composed of four stanzas of four lines each with no more than eight syllables per verse and with assonant rhyme in the even-numbered lines. Poets of the Generation '27, such as Federico García Lorca and Rafael Alberti, cultivated this poetic form. It was García Lorca who designed the original copla format when in 1931, he recorded a series of popular songs called "Las calles de Cádiz" with singer and performer Encarnación López Júlvez.

If I had any power in the firmament this night dark like a well, with a little moon knife I would cut the grilles of your jail. If I were the queen of daylight, of wind and sea, I would tie myself in slave ropes for your freedom

Ay sorrow, little sorrow, sorrow... sorrow of my heart that flows inside my veins with the strength of a cyclone It's like a cloudy spell, of darkness and flint it's a runaway colt that doesn't know where it's going It's a sandy desert -sorrow- it's my glory in a penance Ay penance, ay penance ay sorrow, little sorrow, sorrow!

I don't want flowers, money or cheers, I want them to let me cry your sorrow, and to be by your side, my dear drinking the tears of your loneliness My eyes hurt as I look but cannot see you, I hate myself Guilty for your bad luck, my April roses

Antonio Quintero (dramatist), Rafael de León (lyricist), Manuel Quiroga (composer). https:// lyricstranslate.com.

2 Stephanie Sieburth, Survival Songs: Conchita Piquer's 'Coplas' and Franco's Regime of Terror (Toronto: University of Toronto Press, 2014), 46. This is the first scholarly book on the copla, a popular genre of music during the 1940 s and 1950s. The performers were mostly women: Concha Piquer, Juanita Reina, Imperio Argentina, Estrellita Castro, Lola Flores, and Marife de Triana, to only mention a few, became the equivalent of Hollywood stars for the Spanish audiences during the 1950 s and 1960s. Likewise, gay men identified with the copla genre, including Rafael de Leon. Miguel de Molina, the most iconic gay male copla singer, was brutally persecuted and lived in exile during the dictatorship. The cross-dressing community has been portrayed in Pedro Almodóvar's films. Some other works on the significance of the popular flamenco music and cultural politics include José Colmeiro, Memoria histórica e identidad cultural: De la postguerra a la postmodernidad (Barcelona: Anthropos, 2005); Jo Labanyi, "Musical Battles: Populism and Hegemony in the Early Francoist Folkloric Film Musical," in Constructing Identity in Contemporary Spain, ed. Jo Labanyi (New York: Oxford University Press, 2002). In 2009 the Biblioteca Nacional de Madrid offered an exhibit recorded in the catalogue entitled La copla en la Biblioteca Nacional de España. 
Stephanie Sieburth's Survival Songs: Conchita Piquer's 'Coplas' and Franco's Regime of Terror draws from Freudian concepts such as repression, projection, and "working through" ${ }^{3}$ to explain the psychological power of these songs. The coplas offered the vanquished the opportunity to express the pain they were forced to repress in the context of the regime's new "normalcy." They also offered a space of recognition not only for the vanquished, who listened to the lyricists' anguished stories of prostitutes, sailors, and the down and out, but also for the victors who saw the genre as the ultimate cultural marker of Spanish national identity. ${ }^{4}$ The pathos, tragedy, and artistry of the coplas, though, are not completely fiction. They are rooted in the authentic experience of the Spanish people.

The story of Luz, my father's younger sister, unfolds like a copla. It is full of pain and suffering that morphs into something heroic at its conclusion. It is a story that informs as well as entertains, giving quiet dignity to the suffering and perseverance of a generation of working-class women growing up in the shadow of Franco's Spain.

I remember the sounds of flamenco blasting from my Aunt Luz's home.

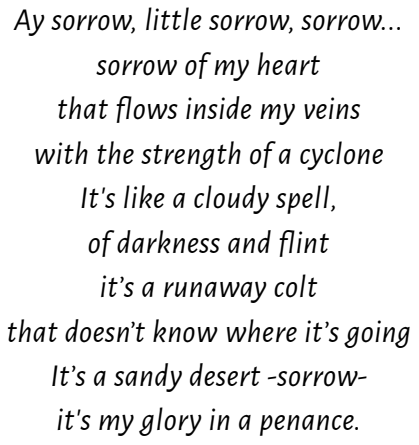

Luz's husband Miguel was crazy about flamenco and an avid aficionado of coplas. His favorites were the usual suspects: Lola Flores, Mari Fe de Triana, and Juanita Reina. "He liked flamenco a lot," Luz explained. "Mari Fe especially; he liked her voice a lot. When Mari Fe came to the theater, he took me to see her." ${ }^{5}$

Sieburth, Survival Songs, 7.

4 Sandie Holguin, Flamenco Nation: The Construction of Spanish National Identity (Madison: University of Wisconsin Press, 2019); Alfredo Grimaldos Feito, Historia social del Flamenco (BarceIona: Ediciones Península, 2010/2015); Alberto del Campo and Rafael Cáceres, Historia cultural del Flamenco (Almuzara: Edición Almuzara, 2013). On the history of bullfighting, see Adrian Shubert, Death in the Afternoon: A History of the Spanish Bullfight (New York: Oxford University Press, 2001). 


\section{Lux/Lucem/Leuk ${ }^{6}$}

Luz is petite, with enormous brown eyes and a piercing laugh. Her hands, all day immersed in water, are pink and puffy. Not a natural blond, she started bleaching her hair when she was young. It was part of practicing her trade of coiffeur or coiffeuse, a hairdresser. She was born on the tenth day of November in 1945, right in the middle of the hunger years, following the unexpected death of another baby girl, María Luz. Her family economized even in the choice of names, recycling the name of Luz and only dropping María from the dead sister. María Paz, the second oldest sister, was the self-designated guardian angel of the new baby and would be Luz's angelus novum.

Luz was never particularly affectionate to me or my siblings when we were children. She was, at best, indifferent. This puzzled me at the time. What would have made her so distant from her brother's family? Over the years, though, I have developed a more meaningful relationship, and even more importantly, an appreciation for her. Whenever I go back to Spain, I always make a point to visit her, and we enjoy long conversations about the family, her life, and my work. Now in her seventies, she is a kindred soul, offering up alternating spoonfuls of unadulterated wisdom and affection. To say that she has mellowed would not be exactly the truth. There is nothing mellow about her. Life's tragedies have smoothed some of the rough edges, but I also have come to see her in a different light.

I was born on Calle Real de Cartuja. And I was a very calm girl, but very vivacious. I liked to play a lot with scraps of fabric, making rag dolls. I went to a school called Divino Maestro; my mother signed me up for the school canteen to receive daily lunch. One day, I'm going to tell you, one day the nun...they served beans ... and that nun made me eat three servings. I got so sick with bad indigestion...vomiting.... And I didn't want to go to school anymore.... Well, I was about 8 years old... and I already left school, played truant from school. I would leave with my girlfriends, we would go down the San Antonio road to the hill known as El Tambor. We ran, and sat around, and picked wild flowers and when we came back home my mother would ask me; "Why are you coming home so dirty?" and I would say, "I was playing in the school patio during recess."

I ended up leaving school because I didn't like the food they served. I told my mother, "Look, Mom, I'll go to school, but I won't go to the dining room, because of that nun Sister Manoli." ...She was a horse, that nasty woman...made me eat that awful food twice!! She would not leave me alone. Every opportunity she had she would punish me by pulling my ears. So, whenever I saw her, I would see the devil!! I didn't want her near me at all. And so,

6 Meaning “light," brightness, from Latin Lux/lucem and proto-Indo-European root Leuk. The latter is the root of Leukemia. 
my mother said, "All right, if you do not want to go to the dining room, you come home for lunch." That was that for a couple of more years.

When I turned ten, I made my First Communion in the church Cristo de la Yedra. I wore a beautiful white, short dress made by a dressmaker named Mercedes who lived on Cazorla Street. A lovely dress! My mother also took me to get a perm at the Navarretes' beauty parlor, in our neighborhood.... but they burned my scalp! And to top everything off my ears got infected too, when my mother got me some new earrings. [She laughed] The whole ordeal was terrible. It does not show in my portrait, you know. They took me to have my picture taken at Reyes Católicos Avenue Photography studio.... And, oh yes! they made a special merienda of chocolate and churros to celebrate [she said with a singing voice] and nothing more...that's it.

As soon as I turned 13, I left school for good and started to work. First, my mother wanted me to learn to sew in order to become a dressmaker, but I hated it. When I turned 14, I started to work as an apprentice at a beauty parlor. But I developed eczema on my hands, so I had to stop working at the salon, though I really enjoyed it. And then I found work in a noodle factory where I stayed for two years. In the noodle factory the machines resembled looms, where they produced the pasta, and we would cut it and package it. That was my job. After two years that factory closed, and I got a job at a bleach factory on Calle Real. I washed glass bottles, removed the seals from the bottles, and filled them with bleach. I left the bleach factory not long after I started. Then, I started working in a chocolate factory but also stayed only a very short while. I guess I just didn't fit in anywhere. They paid so very little... 6 pesetas...SIX PESETAS!... and in the noodle factory I was paid TWO PESETAS... a week!! TWO PESETAS!! It was around the year 1959 or so. 
Figure 41: Luz as a young girl

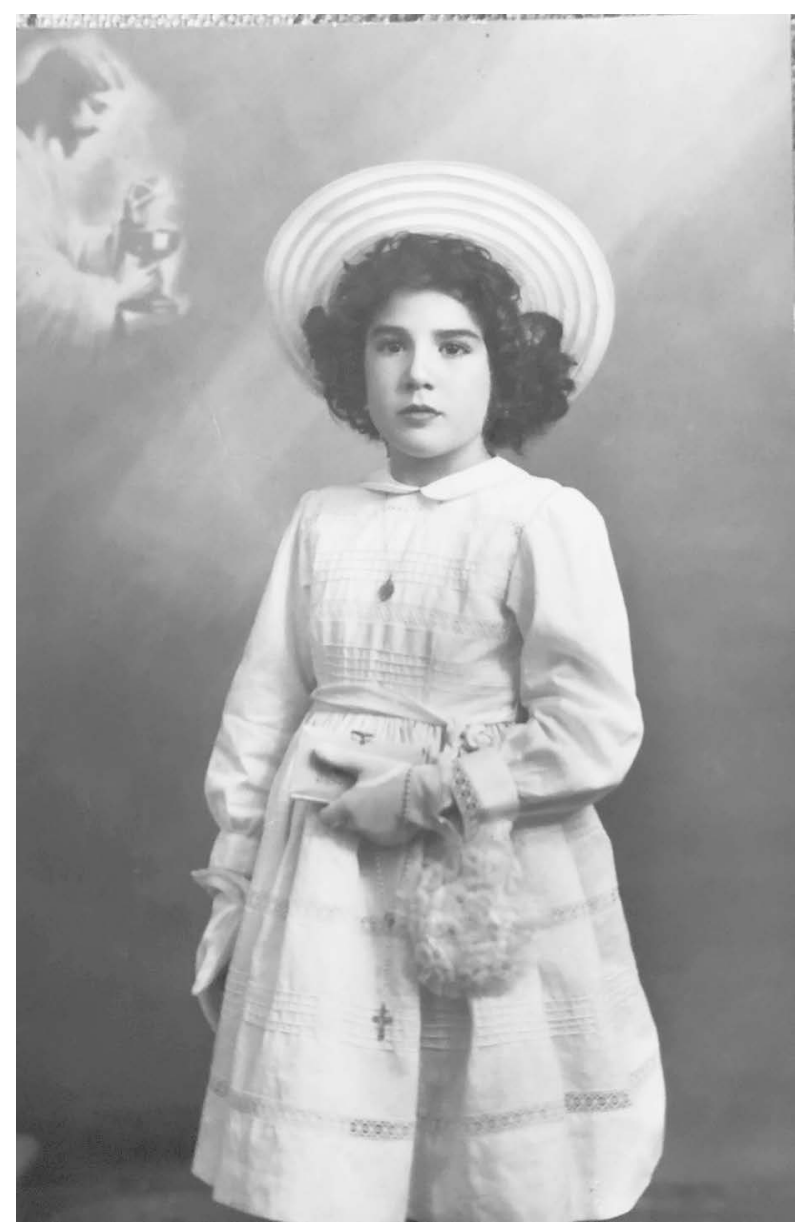

In the end, I decided to go back to the hairdresser business. I looked for a job in a salon in Calle Recogidas called Isidro Hair Salon. The owner made a pass at me; it was very unpleasant. He told me, "Well, we need to test you to see your skills and decide if we are interested or not in having you stay." Well, well, I didn't know what his intentions were, of course,...so I did the task just fine...but that so-called fine man only wanted to take advantage of me! And I told him...NOT AT ALL! [She paused with indignation, remembering his advances] The same thing happens now with bosses. They always want the same thing: to harass you [She meant sexually] but I said...NO! Well then, since I didn't succumb...and I had done 
the test just fine...well, that so-called respectable fellow threw me out. I filed a complaint with the police, but he didn't show up, of course. I turned around and left to look for work in another salon where I ended up staying ten years. By then my hands had gotten used to the water or chemicals or whatever, so no more eczema.

Luz was fifteen years old when she met her future husband, Miguel. She fell head over heels for him. He lit her fire, not like Jim Morrison but rather like Manuel de Falla's bewitched love.

$$
\begin{aligned}
& \text { Lo mismo que el fuego fatuo } \\
& \text { Lo mismito es el querer } \\
& \text { Le huyes y te persigue } \\
& \text { Le llamas y echa a correr }
\end{aligned}
$$

Their love story unfolds like a copla with its intense emotions leading to its ultimate, inevitable tragedy.

I used to go out with my friend Mari Trini who also lived on Calle Real.... One day she said, "Let's go to that dance where the boys hang out on Hornillo Street," and I said, "Well, sure, let's go." I added, "But, girl, how are we going to go like this? We are dressed like little girls...they won't let us in!" But she insisted.... "Well, let's see what happens." So we were able to enter the party, and I saw Miguel and right away I liked him! And you know what happens. Boys ignore you and you... as a young girl, because we were so innocent and young...kept coming back on other Sundays. My friend started dating one of the other boys, and we all started to go out together every Sunday. The photos of those times are hilarious. When carnival came around, we used to throw parties and get dressed up. [She laughed while showing me the photos] Miguel was a king and I was a princess. All dressed up, we went down Gran Via Avenue to eat some cake. I remember the "gypsy's arm" "...it was delicious...in the Alcazar confectionery. Your parents had already gotten married and they moved to the same street where Miguel's family lived in Calle San Isidro. My family was not happy about my seeing Miguel.

7 Like phosphorescent fire is love When you run from it, it follows you If you seek it, it runs away [my translation], excerpt from, "Canción del fuego fatuo" or Song of wildfire (Will-o'-the-wisp) in the ballet composition El amor brujo (1916) by Manuel de Falla (1876-1946) and libretto by Gregorio Martínez Sierra (1881-1947).

8 A sponge cake roll dessert from Spain. https://www.spanish-food.org/desserts-spanish-swiss -roll.html. 
Figure 42: Luz and Miguel in costume

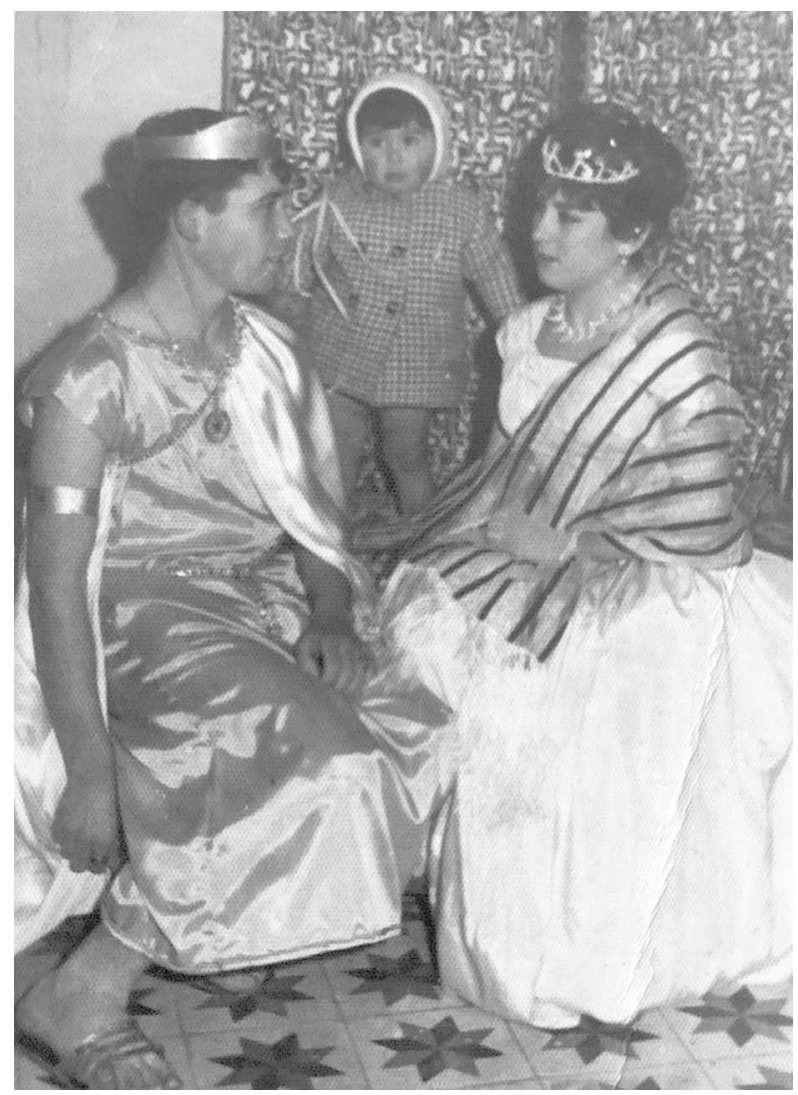

Every day a fight...an argument... they beat you... would say, "I don't want you to go down there...don't go...don't go looking for him...that's not your place...to go looking for him...HE should be the one who comes to you..." You know how it is. But the more they told me not to do something the more I wanted to. It came to blows and a slap, but I said, "I don't care how much you punish me! I will do as I please!" [She paused] I was only 15 or maybe 16 years old, so very naive [In a reflective tone she goes on] You know...If I had known better, like I do today, I would have not disobeyed. To tell you the honest truth, I should have had more self-esteem; I should have made others see my worth.

And I spent every day...EVERY DAY, morning, afternoon, and night, at all hours, in his pursuit. I was so in love with him [She paused a moment] I could not see anything else. I could not see he had no future...because he really had no future...but I was so very young. 
Her pleading eyes, as she recounts her love affair, resonate with the Lorquian cadence of Zorongo:

I have blue eyes, I have blue eyes

and my little heart is just like the tip of the flame.

By night I go out in the courtyard and I cry until I'm spent

seeing that I love you so much and you don't love me at all. ${ }^{9}$

One day, I wanted to go to the wedding of a friend in the neighborhood. My mother told me, "You are not going to the wedding! I told you, you are not going to the wedding! Much less with that boy." I escaped through the window. ${ }^{10}$ I jumped out the window to the patio and went to the wedding. We came back at three in the afternoon. Auri, WHEN I SAW MY MOTHER AT THE DOOR I said, 'Miguel, go now!" and he replied, "Why do I have to go? I haven't done anything wrong." My mother slapped me so hard that blood ran out of my nose. Luz silently looked at me and then in a whisper she said, "That was the way." And I told myself, "Well, you hit me.... I don't care."

Miguel wanted to come to the house to ask permission from my mother and father to be my formal boyfriend, but then my father died. Then he (Miguel) came to the wake, asked for a chair, and sat there among everyone else... and after that moment...after that day of the wake he started coming to our house regularly. That was how our official engagement began! He just asked for the chair to sit and pay his respects when my father was already dead and we were watching him.

We saw each other very little because he had to work with his sister in her churro shop. Many times he came to pick me up too late. My mother always told us, "Do not come back later than nine!" I took little Pepe, my nephew, as our chaperone. I had to take the child even though I did not like to have to bring him. ...I thought, "What can my boyfriend possibly do to me?... My boyfriend... a kiss and a hug?" I told my mother, and she would not budge. "I do not know what, I do not know how much...patatín, que patatán."

Tengo los ojos azules, tengo los ojos azules Y el corazoncillo igual que la cresta de la lumbre. De noche me salgo al patio y me harto de llorar De ver que te quiero tanto y tu no me quieres nà.

Federico García Lorca, Zorongo, https://lyricstranslate.com/en/zorongo-zorongo.html. 
Figure 43: Luz and Miguel at the fair

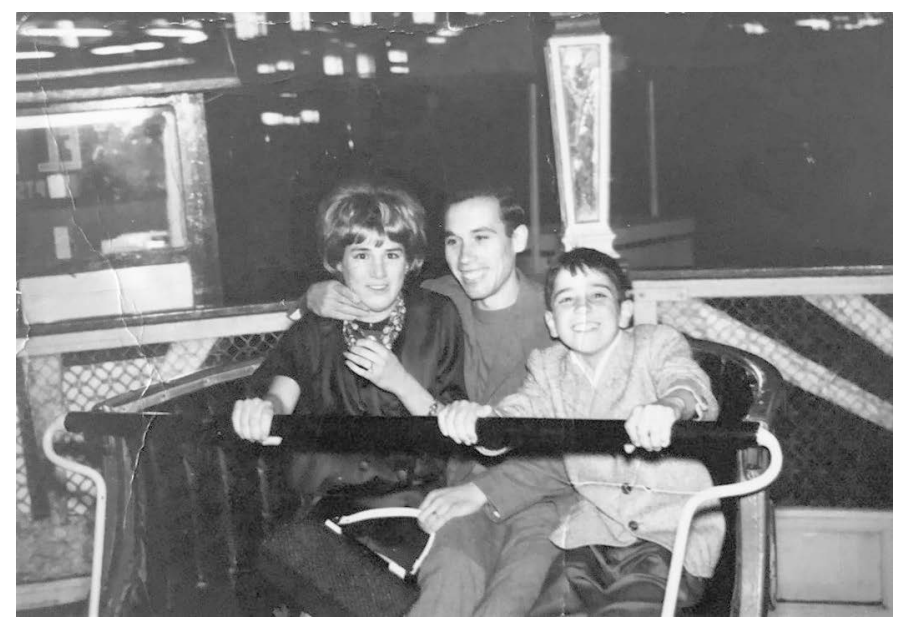

The moon is a shallow well, the flowers aren't worth anything, what is truly worthy are your arms when they hug me in the night, what is truly worthy are your arms when they hug me in the night. ${ }^{11}$

One day we wanted to go to the cinema. Miguel came to pick me up with the tickets. I can see him now as I am talking to you. I said, "I don't have any stockings! And I don't have high heels!" But Concha [her oldest sister and Pepe's mother] had bought some spectator perforated pumps in black...beautiful! And she also had silk stockings. So, I said to myself, "These things, I'm going to wear them!" I remember that day. I wore a nice pretty flowery dress with a bolero jacket. Then, I put on the pumps. Before I put on the shoes, Concha had warned me, "Do not even think about wearing my new shoes. I haven't worn them yet," and I replied, "No, no... I don't wear heels and don't know how to walk in them; why would I do that?" And my mother also told me, "Don't wear your sister's shoes. She will start fighting and raging." And I said to myself..."Right, why not? I am wearing those shoes AND THE SILK STOCKINGS...TODAY!" Well, once outside, I put them on. I went out the window into the patio [She looked at me with mischievous smile] so my mother wouldn't see me. I took

11 La luna es un pozo chico, las flores no valen nada. Lo que valen son tus brazos Cuando de noche me abrazan. Lo que valen son tus brazos Cuando de noche me abrazan. García Lorca, Zorongo. 
the shoes in their box. Then took off my shoes and put the new ones on. I placed mine inside the box and threw the box into the bedroom through the window.

As Miguel and I were walking down Dr. Oloriz street around the area where the Granada garage was at the time, one of the heels broke [She laughed loudly] and with great alarm I told Miguel, "Oh if we don't fix this heel they're going to kill me, THESE SHOES ARE NOT MINE!!!" So, we decided to go into the Granada garage and asked the man who was there on guard, "Would you have a hammer and a nail? My girlfriend broke her heel, and she is limping." Well, the man went in the back and found the tools to hammer the heel...badly...and I said to Miguel, "Let's go." I was barefoot then; "Let's go, I don't want to wear these shoes anymore." When I came back home, I cleaned the shoes very well, took off the stockings and realized I made a big run in them, and I thought, "Oh, no!" This happened on a Saturday, and on Sunday my sister went to put on her new shoes, and she screamed at the top of her lungs, "MY SHOES ARE BROKEN. YOU WORE MY NEW SHOES." Oh my! She started a big fight.... What a disaster... My mother hit me, pulled my hair.... And I said, "But, aren't you ashamed to hit me now that I am already so big? I am fifteen years old; aren't you ashamed of hitting me?" "Noooo, because I warned you... I didn't want you to put on her shoes, I didn't want you to wear her stockings."

The rebellious temperament of a young woman in those times was risky business. Luz was mischievous, but not malicious. Obdurate, impertinent, indomitable. There was no punishment harsh enough to change her. She wanted Miguel and she would have him. Their courtship lasted nine tempestuous years.

You know how things are and what happens when people are dating. Some days, you are all right, get along and other days you are in a bad mood, regretting the day you laid eyes on each other. I was working at the hairdressing salon and, on the side, also started working at home. And I remember telling the girls at the salon where I was working, "When I get married, I will not work anymore," and one of them said,... I can almost see her now as I remember this...her name was Conchi, "Don't believe that, honey; you will work until you die." And I said, "Oh please don't tell me that, Conchi, I don't think so. My boyfriend works at his sister's churro stand." Then shortly after, out of the blue, my boyfriend said, "I would like to learn your trade." I could not believe my ears, "Oh, my God!" I said. So he started coming every Sunday, after he finished working at the churro stand. He learned to put curlers on, wash hair, prepare and apply the coloring dyes.

This stopped when he got drafted into the military. They sent him to Viator, Almeria. My boyfriend was already coming down with some bad stomach illness!! When he returned from his service, I decided to quit my job in the salon where I was working and go into business with him. I remember how difficult it was to tell my mother. I said, "Look, Mamá, I am quitting the salon because I am opening one with Miguel." She was so upset. "What are you talking about?" she said, "You cannot stop providing your wage here at home." "Mamá, please, wait, let me explain myself... a m planning to bring my same wages to you every week," and she 
replied, "Sure, you say so now... I do not want you to quit your job.... You have no idea what you are getting into, leaving your job and starting a business with your boyfriend, you alone with him? My God... what will people think? What about your reputation?" I told her, "I am twenty years old and I know how to take care of myself." In the end she accepted my decision, as she saw I was not going to change my mind.

Miguel and I rented a flat for 2,500 pesetas per month. My mother was terrified. "How are you two going to be able to pay that rent? You only charge 25 pesetas per head!!" I reassured her; it is true, we had to work very hard to make the rent every month plus pay for utilities too: water, electricity, and the business license. To be honest, Miguel gave me the seven pesetas I used to make in my old job, but you know I once complained to him, "So you give me the seven pesetas I used to make in my job, those same seven pesetas I give to my mother, and I am so overworked here from eight in the morning to ten at night. For just seven pesetas!" And he would tell me, "Well, whatever we can save will go to our wedding fund," and so on. So, I thought, since I only get seven pesetas and I have to give them to my mother, I will start working on my own at home on Sundays to make some extra money for my expenses. And I did get lots of customers on Sundays, but of course those people stopped coming to our beauty parlor. Anyway, the business prospered a little, one way or another, and we hired some young girls, apprentices, you know. One of them, a girl named Clara, started flirting with Miguel, and he was flattered. Ha! So, I told him, "Look here, this can't continue. We are either going to get married or break up. I will split the business with you too. That means the three standing hairdryers I bought will come with me, and you keep the single one you purchased."

I had taught him the trade, and he thought he was going to be my boss? ${ }^{12}$ What nerve. I was the one working fourteen hours a day and making seven pesetas a week. When I questioned him about that girl, he would say I was hallucinating. "No, no, no, no; I am not imagining things," I told him. "The customers are the ones telling me what you two are up to. Do you think I am stupid?"

Despite their problems, they eventually did get married.

12 The regime first re-enacted the 1889 Civil code in 1938, and there were no reforms until 1958. Even under this legislation, women were legal minors and needed permission from their husbands to even open a bank account. See Morcillo, True Catholic Womanhood. 
Figure 44: Luz and Miguel outside work

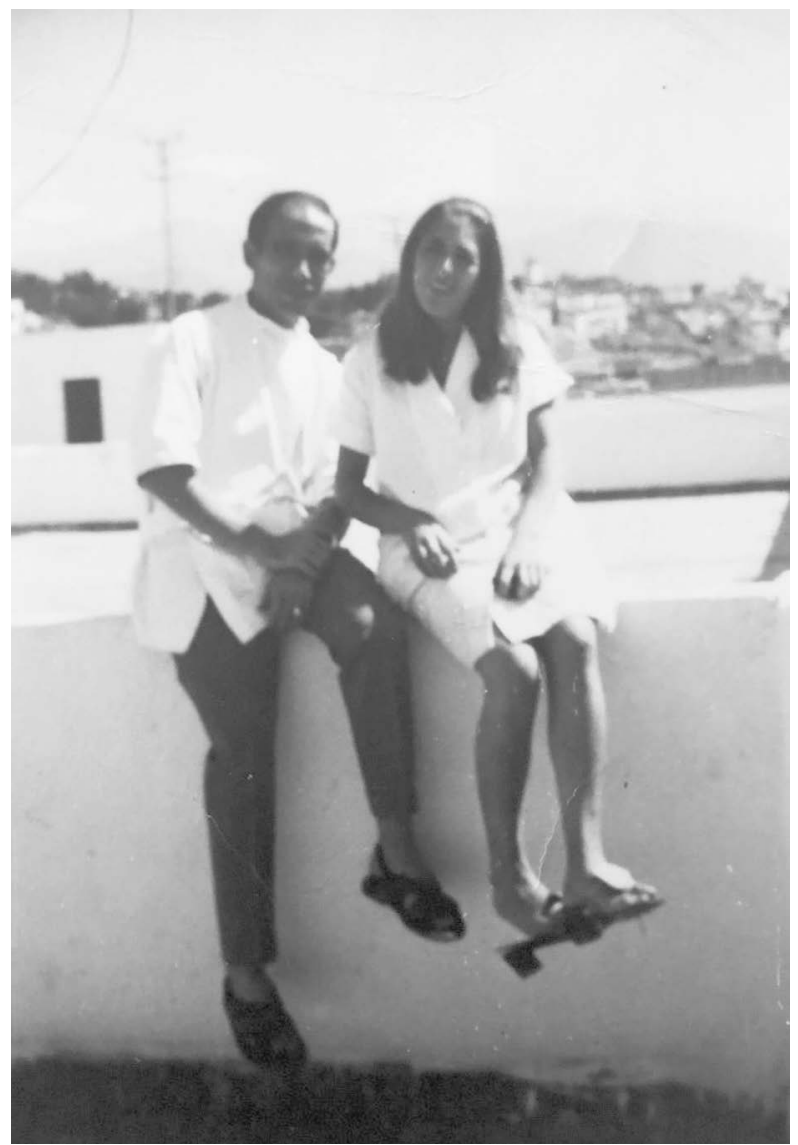

After the wedding celebration, we went down to our apartment. Although it was late, we went for a walk. And I remember my mother had told me, "Girl, cover the sheets with some towels when you go to bed." And I wondered, "Why towels on the bed? What will happen to me on the wedding night? What is my mother trying to tell me? What is the wedding night about?" I was so uninformed. I went ahead and laid my towels on the bed. Miguel looked surprised. "Why do you put that on the bed?" I said, "Because my mother told me to, just in case the bed gets dirty." [She laughed] And he said "Oh, come on!!!" He was more worldly than I. Well, the wedding night passed. And I thought, "That was a big disappointment." Those were my thoughts. "THAT WAS IT?" I might be a very cold person; sometimes I would tell him, "Stop!!! you are hurting me!! I can't stand this; I can't stand this!" Really, instead of enjoying myself the whole thing was an ordeal. [She spoke in an indignant tone] The 
morning after the wedding night, someone knocked on the door very early, and IT WAS MY MOTHER-IN-LAW. I felt so embarrassed and ran into the closet. I didn't want to come out. I felt so mortified to have to see her!!! [She said emphatically] I don't know why she came. [She spoke outraged with shame] AH! BREAKFAST!!! BREAKFAST?!! The sweet woman did it with good intentions. Miguel opened the door and let her in, and she asked, "But where is Luz?" And he, amused with the whole scene, replied, "Well, she's in the closet. She doesn't want to come out." And I was so ashamed...SO ASHAMED!! [She almost blushed again] That was my wedding night. NADA!!

Figure 45: Luz and Miguel's wedding photos
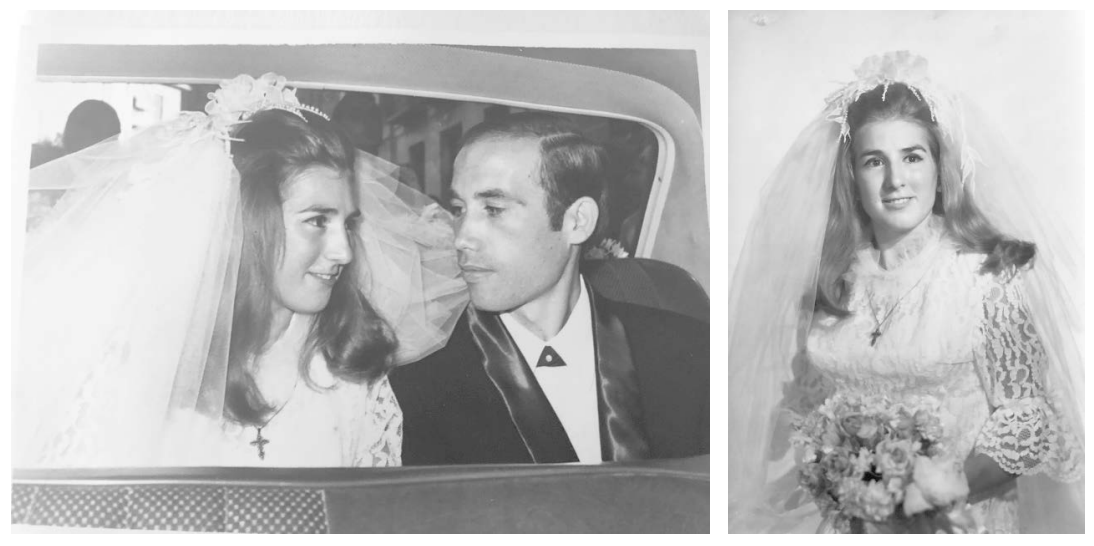

I could not get pregnant, so I had to go to the doctor. I remember my mother-in-law accompanied me to a very invasive test. I got so sick after it that when she saw me coming out, she told me, "As soon as I see my son, I will tell him there is no way you can have any more of these tests. It does not matter if you don't have any children."

Eventually, Luz and Miguel got pregnant; not once but twice. Two sons came five years apart. Miguel started to get sick right after the first baby was born. That was the beginning of a very painful time.

Miguel started to get sicker when the first baby was born. He managed to last almost fourteen more years before he died, but each year he became sicker. He was only forty-two when he died. The youngest boy was eight and the oldest fourteen. My mother died in July and Miguel had stomach surgery in August the same year. Exact years and dates don't stick in my head. Yes, he was 42. He had stomach cancer; he was so very sick, truly sick, sick. The doctor did not want to alarm me by telling me about the cancer at first, so I wondered all the time, "Why is my husband so very ill?" His skin turned yellow. He was vomiting all the time. I decided 
one day I had to talk to the doctor, and he questioned me, "Luz, you really don't know the kind of ordeal your husband went through?" and I said, "I just thought he had stomach surgery." Then he revealed to me what the reality was. "We removed the stomach completely because your husband has cancer." She slowed down her speech and looked at me with sad eyes.

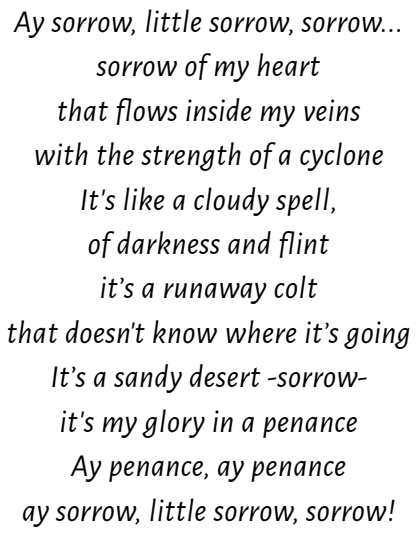

I walked out of the hospital weeping, barely breathing, as if I had lost my mind. Everything we had suffered started to make sense at that moment. He had been sick many nights, and we had had to rush to the emergency room [she told me this in a whisper] at two, at three, at four in the morning. That time when he had awful itching...horrific itching.... That must be the worst possible thing to suffer. One day I remember, I arrived home from the salon and found him all burnt, his skin raw, because he got so close to the stove to alleviate the itch. Apparently the heat helped. I arrived and found him, poor creature, all burnt, with blisters all over, and I asked him, "My darling, what have you done?" and he tearfully replied, "Oh Luz, Oh honey, I am so sick, I am so very sick; I am dying. I will jump out that window," and I yelled, "What are you talking about? WHAT ARE YOU TALKING ABOUT? JUMPING OUT A WINDOW?" Nothing more...one day, and another day, and another day... [she hit the table with her fist].

The hands of my love are weaving a cape for you with a trim made of wallflowers and a hood made of water. When you were my boyfriend, back then in the white spring, 
the hooves of your horse

were four sobs made of silver. ${ }^{13}$

Nine years.... Well, really almost from the very moment I met him, Aurorita!!

After I had my first baby, they did the surgery and the doctor told me, "We have fixed him for another five years or so." He improved so much and that's when I got pregnant with the second baby...in those five years. And I thought, "The doctor lied to me; he doesn't have cancer." And I went to see the doctor and said, "You know, doctor, I think you might have made a mistake." And he replied softly, "No, Luz, dear, I did not make a mistake about your husband's prognosis." Sure enough, Miguel started to get sicker again, yellow again, pain on the side, pain in the stomach area. Now I found myself with two little boys and a sick husband to look after.

He could barely work. I was working at our salon, taking care of the housework, [she changed the cadence of the speech to reflect the monotonous routine], the kids...taking them to kindergarten.... One night, I had to leave the house at three in the morning, alone. Go down those dark streets looking for a taxi. He vomited, and I had to gather some of it from the bucket where he puked to take it to be analyzed to the hospital so they could determine what was wrong [she stopped talking and looked into my eyes intently.] Auri. That?! That was the worst.

As he was really sick, he was always in a bad mood...always fighting, irritable around the children...yelling at them, spanking them. Many times, I pleaded, "Don't you pity them? They are so little; that's not something one does." [she spoke with an imploring tone, as if Miguel were in our presence] He would spank them on the butt or slap them on the face, and I would tell him, "Miguel, for God's sake, that is not something to do to little children. You make me suffer." But then I would reflect and tell myself, "He is not well." He developed a horrible temper. I had never seen that before, not when I met him. That was the disease acting out.

13 Las manos de mi cariño te están bordando una capa con agremán de al helíes y con esclavina de agua. Cuando fuiste novio mío por la primavera blanca, los cascos de tu caballo cuatro sollozos de plata. García Lorca, Zorongo. 
Figure 46: Nieces in flamenco dresses

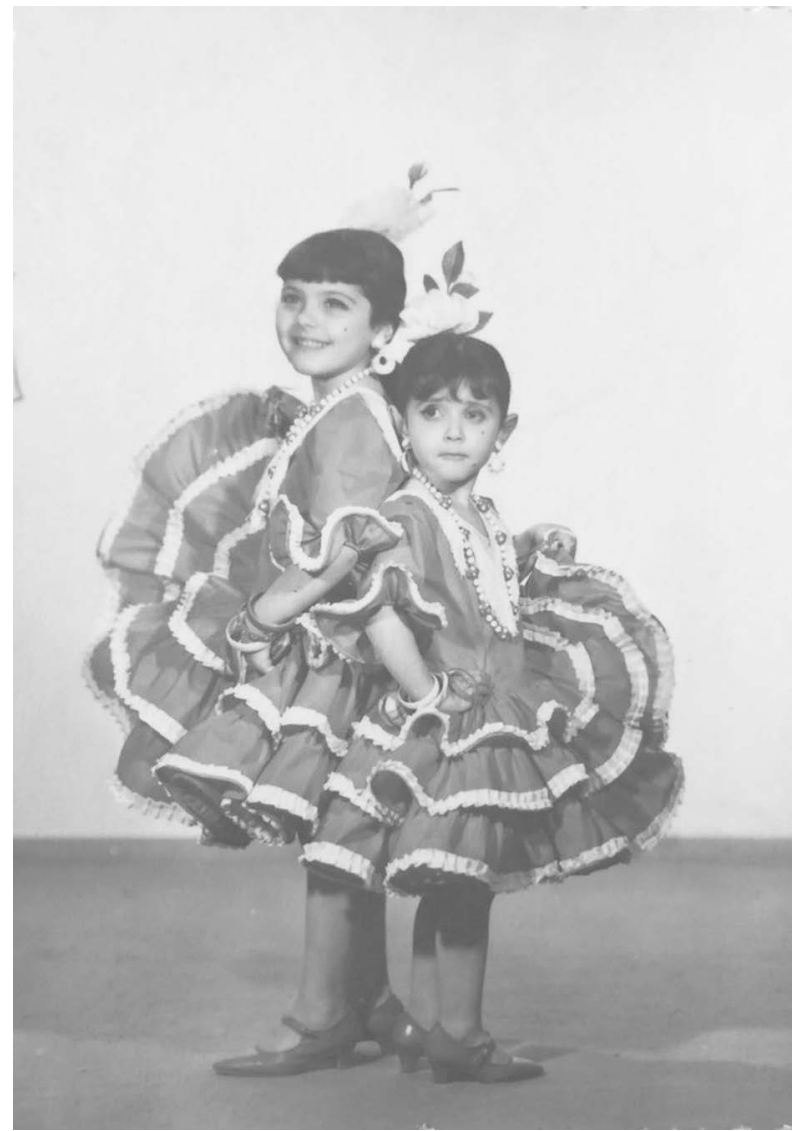

Well, I liked him. I liked him the minute I saw him. I felt my heart stop!!! Auri, when I saw him, I knew, "That one is mine, my destiny." That's what I think, Auri!! To tell you the honest truth, I feel I was more in love with him than he was with me. [She spoke softly with revealing emphasis] I was blind...crazy about him. I had met another guy, but only for a short time. MIGUEL was the only one. After he died, no one else, never...nothing. I suffered enough, you know? One day, and another day, and another day, and another day, and another day [her voice rose in crescendo] AND ONE MONTH, AND ANOTHER MONTH,...AND ONE YEAR, AND ANOTHER YEAR...THAT WAS NINE YEARS. [She stopped. Then continued] With a disease. I got married in [19]70. And he died in [19]86!! [She looked at me with indignation] How about that? Sixteen years married and nine more dating. 
García Lorca considered songs, like people, living entities.

The songs are creatures, delicate creatures, which must be taken care of, so that their rhythm is not altered at all. Each song is a wonder of balance, which can be easily broken.

$[\ldots]$

The songs are like people. They live, they improve, and some degenerate, they fall apart until we only have those palimpseptos full of gaps and contradictions. ${ }^{14}$

My aunt's life was like the copla lyrics Miguel used to listen to, blasting from their record player at every family gathering. Like the copla, her life was full of passion, defiance, and ultimately tragedy. A cancer devoured her only love, right in front of her eyes. She was so close to happiness but was robbed of it by her husband's illness. Miguel was never able to be the man she thought he was. The sickness turned the handsome flamenco-loving young man into a bitter and unloving husband and father. So much hope, yet so much disappointment. No one's fault but fate. ${ }^{15}$

She continued talking in her wounded tone:

That's why I tell you.... If I had known better...I swear to you.... I told my mother one day, I said, "Mamá, if I had known how very little enjoyment I was in for in my marriage I would have slept with him BEFORE." [Her indignation now turned into defeated exasperation] ...WHEN I WAS YOUNGER, BECAUSE I NEVER ENJOYED MY MARRIAGE. I DID NOT ENJOY ABSOLUTELY ANYTHING. [She was upset and fell silent] I ONLY DEALT WITH ILLNESSES. ONE DAY, AND ANOTHER DAY, AND ANOTHER DAY, AND ANOTHER DAY.

\section{Pimpan}

Pimpan

Pimpan

"...las canciones son criaturas, delicadas criaturas, a las que hay que cuidar para que no se altere en nada su ritmo. Cada canción es una maravilla de equilibrio, que puede romperse con facilidad: es como una onza que se mantiene sobre la punta de la aguja. [...] Las canciones -prosigue- son como las personas. Viven, se perfeccionan, y algunas degeneran, se deshacen hasta que sólo nos quedan esos palimpseptos llenos de lagunas y de contrasentidos." Federico García Lorca, Obras completas (2006), 459, quoted in Marco Antonio de la Ossa Martínez, "Federico García Lorca, la investigación musical y las Canciones Populares Españolas," Quadrivium Revista Digital de Musicología 9 (2018): 3 https://dialnet.unirioja.es/servlet/articulo?codigo $=6836540$. 


\section{Maruja's Brilliance}

Figure 47: Maruja

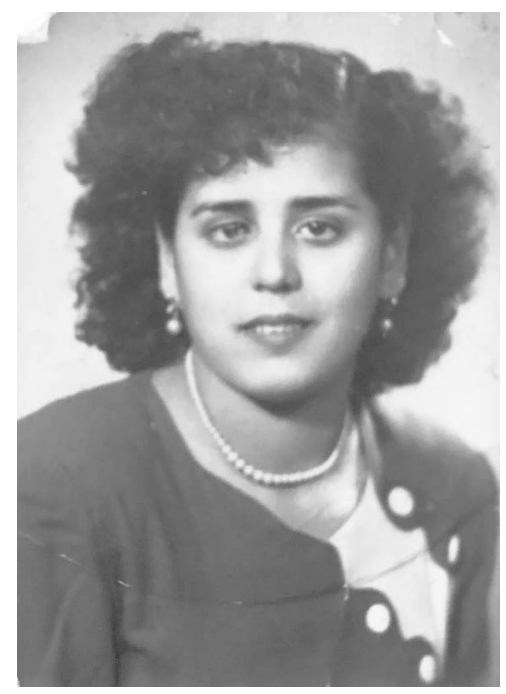

Maruja was in the hospital when her father broke the news. The new baby was a girl and they decided to call her Luz. "Luz?" she asked, puzzled, "what kind of name is that? Where did you find it?" "Oh well," he replied, ignoring the question, "We liked it."

Maruja, Luz's older sister, had been in the hospital for a few months after a lifethreatening accident. The accident was horrific. She whispered into the cassette microphone the memory of it all:

I had gone to a friend's house after school, but my mother had to go shopping. She had been pregnant before with a baby girl who died [You know,...the one who died?] and was pregnant again. It was then that my mother told me, "Maruja, come over, I am going to Hornillo Street to shop. I want you to blow the brazier." I used to go fetch the wood from the factory where my father worked, and he would give me a sack, a basket of firewood. So, as usual, all the kids were around me to get warm, and then I was blowing at the brazier. There were two boys in a car from El Fargue ${ }^{16}$ where the military powder magazine was located, you know?

16 In his study of the powder factory of El Fargue, Francisco González Arroyo tells the important history of this site. In his thesis, he argues that the factory's history goes back to the year 1230 , "almost certainly" to the existence of two powder mills before the Nasrid period. There 
They made bombs there. The driver was going to fetch children at the school and take them home. But in the house next door to where we were standing there was a pile of sand, a lot of sand. Of course, as the guy was driving so fast, he did not see the pile of sand, drove into the sidewalk, and hit the lamppost and it fell on me. It took me rolling all down the street. The lamppost...of course...it was made of iron. I went rolling, rolling, rolling. Well, I almost reached Hornillo Street where the lamp stopped. They called my poor mother. "Emilia, there has been an accident!" Well, they took me to the hospital. My poor mother, I could no longer see her. I think she had the baby girl in the summer in July. She gave birth and I was still in the hospital when they told me the name of the new baby. They did not plaster my entire body, but they plastered me from here [She pointed to her hip] to the very tip of my foot. All this is a fake bone. [She touched her thigh to show me the length of the prosthetic bone they implanted]. ${ }^{17}$

Maruja spent a year in the hospital. The cost was covered by the army as it was one of their vehicles that almost killed her. She was thirteen when she left the hospital and started to work. First, she learned to sew in a tailor's shop. A quick learner, she became skilled at sewing all the suit pattern pieces. Proudly she told me she was able to complete a full suit, trousers, vest, and jacket. One of the employers she worked for gave her extra work to take home.

I sat on a chair that I placed on top of the table in the main room in our home in order to be able to see the sewing. There was a weak illumination from a lightbulb of 10 watts or so. Then later, when readymade clothing started appearing, and my eyesight became worse and worse, I sought work braiding the cane seats of chairs. I used to work outside our front door in the

is evidence of the production of gunpowder in the Muslim era and during the subsequent reign of the Catholic Monarchs, who delegated management to the governor of the Alhambra. The mills came under the control of the Royal Treasury during the Napoleonic occupation (1810-1812). In 1819, two private companies ran the factory until 1850, when the Artillery Corps assumed technical management in collaboration with the Royal Treasury. In 1865 the army took control of the mills. In El Fargue projectiles, torpedoes, and breaker grenades were used successfully, according to the press of the period, in the war with Morocco well into the 1920s. According to Conzález Arroyo, the high point of production took place during the Civil War: "The factory was from day one the main reason why Granada was a crucial target for the Francoist troops, because it could guarantee them the ammunition supply they needed." During the conflict, more than 980,000 kilos of gunpowder and more than 1,250,000 kilos of explosives were produced. There was hardly any dependence on the outside. Almost everything in El Fargue's high tech factory was locally made. Francisco Conzález Arroyo, "De la Real Hacienda al Instituto Nacional de Industria pasando por Artillería 1850-1961" (thesis, Universidad de Granada, 2013) https://granadaimedia.com/la-fabrica-que-decanto-la-guerra/.

17 María Morcillo Miranda, interview by author, Granada, October 23, 2006, tape audio recording. 
building courtyard. Whenever there was nothing else to work on, I would just go for the day and work in the fields, gathering wood, picking onions, potatoes, whatever, to survive. ${ }^{18}$

In 1961, as the tourist industry took off in Spain, Maruja emigrated to Mallorca, seeking more stable employment as a maid in the hotels on the Mediterranean island. She tried unsuccessfully to convince Luz to come with her rather than get married. She realized after rejecting a marriage proposal herself, that she did not have the temperament to put up with any man. Her freedom was too important to her. After working in Mallorca for a few years, she returned to Granada where she quickly found a job as a maid in the Colegios Mayores. ${ }^{19}$

18 Morcillo Miranda, interview.

19 In Spanish universities, from the late Middle Ages until the end of the 18th century, Colegios Mayores or Major Colleges were associated with instruction and conferral of undergraduate and graduate degrees (bachelor's and doctorates). In addition, the colleges provided accommodations for students. Sometimes they were an extension of a university and other times gave birth to universities. They functioned with great autonomy; the professors taught in the colleges while students would take their exams at the university. The resident students governed the administrative and economic aspects of their college and elected and appointed a rector among themselves. In sixteenth-century Spain there were six Major Colleges; four in Salamanca, one in Valladolid, and another in Alcalá de Henares. Maruja was part of the housekeeping staff in The Royal College of San Bartolomé and Santiago in Granada, founded in 1649. Other European universities also had their University Major Colleges, but the heirs of this tradition were Oxford and Cambridge, where the colleges became the main feature of university life, both as teaching and social life epicenters, leaving the examining functions and collation of degrees to the university.

A decree of September 19, 1789 ordered the extinction of the Major Colleges in Spain due to a crisis of corruption and elitism. There were attempts to re-open them in 1815 and 1831 that did not succeed. In 1910 the Free Institution of Learning established the Residence of Students in Madrid, which sought to emulate the tradition of the English Major Colleges model. Their aim was to encourage broad education and training as an extension and crucial complement of the university life. In 1915 the Women's Residence was created, under the direction of María de Maeztu. The Residence had a formative mission, not only as a residential site for merely 15 students, but with the objective of educating the elite in an exclusive cultured and creative environment. The rationale behind the elitism was to bring Spain closer to the scientific, technical levels of Western Europe. To this end, the most outstanding professors of the Spanish university, distinguished writers, thinkers and foreign scientists (Lorca, Alberti, Buñuel, Dalí, and also dozens of future scientists) stayed at one point or another in the Residence. A decree of August 25, 1926 provided that each university district capital establish a Board with the mission to rebuild and reorganize the Major Colleges. The Spanish Civil War destroyed this venture, although many of the residents and their professors collaborated in exile in the development of Latin American political and intellectual institutions. Olegario Negrín Fajardo, "Los Colegios Mayores durante el franquismo," in L'Université en Espagne et en Amérique Latine du Moyen Âge à nos jours. II : Enjeux, contenus, images (Tours : Presses Universitaires François-Rabelais, 1998) http ://books.openedition.org/pufr/5977. 
Known colloquially as a "scout" in the English parlance, her housekeeping duties were performed during morning hours for the students' and professors' rooms. The rest of her workday included cleaning and maintenance of communal living areas: kitchens, bathrooms, as well as serving meals (breakfast, lunch, and dinner), laundry and ironing.

The Franco regime re-established by decree of September 21, 1942 the Major Colleges with two fundamental goals: the control of the students and the training of the intellectual and political elites of the regime. In the restoration of the Major Colleges, the regime used the national Catholic principles: imperial university, revival of the Golden Age Spanish past, traditional Christian education under the Catholic Church's purview, and finally, rejection of everything foreign. These colleges were segregated by gender. Each college had a chaplain, and all the residents received political instruction in the Falange principles. Other educational purposes stated in the legal regulations included cultural, social, artistic, and physical and sports education. The Education Act of 1970 reformed the Major Colleges. They would no longer be considered elite training places, as in the ideological presuppositions of national Catholicism, nor were they to be the educational centers par excellence any longer. Their new function was ambiguously stated as "formation and educational coexistence." ${ }^{20}$

Maruja witnessed the college life of the privileged male, exclusively law students at the Colegio San Bartolome y Santiago, located in the adjacent area of the Plaza de los Lobos where the students arrested in the State of Emergency of 1970 were taken. Her life, though, was not affected much by the unrest taking place right under her nose. For her, the job provided the stability to be able to live a quiet life and to help her younger sister raise her two nephews.

Luz was profoundly grateful for the support given to her by her sister.

She helped me so much! Since I got married...every day she would come by from College...every day she brought a basket E.V.E.R.Y D.A.Y. Meat, eggs, bread, fruit...EVERYTHING. Apart from that, every month she gave me money. [Luz looked at me with complicity and paused, then continued listing what her sister provided in terms of financial security for her] She paid my social security. One day I was combing Concha's hair [their

The legal text laid the groundwork for the forging of the ideal Spanish gentleman, following the criteria rooted in conservative Hispanic tradition. The decree of November 11, 1943 established the mandatory residence of university students in the colleges unless they were native residents living with their parents. The same decree established the political control of the appointment and dismissal of the rectors, who would be nominated by the Rector (President) of each university, following a report from the Ceneral Secretariat of Falange. The decree-law of October 26, 1956 and the law of protection of Major Colleges of May 11, 1959, solidified the Francoist policy in matters of University Major Colleges. Negrín Fajardo, "Los Colegios Mayores durante el franquismo." 
oldest sister] here in the beauty parlor and Maruja came, like she did every afternoon. At around half past four in the afternoon she would always be here, [Luz laughed with satisfaction while remembering] staying until 9 at night. And my Concha suddenly said to Maruja, "Obviously, you have time to visit with this one, but you don't come to my house to see me. You only love Luz." And Maruja, she might have been in a bad mood, replied, "Well YES! Of course, for sure I love her...MORE than I love YOU!" [Luz paused a little bit to let the story sink in, then gently continued] Then I told Maruja, "Look, why did you tell her that?" "Because it's the same thing all the time, at all hours, telling me that I come to see you too much, that I give you this and that, blah, blah, blah.... And what does it matter to her? She has her husband who earns good money!"21 I did not have anything but my work at the parlor because my husband did not leave me a pension or anything at all. MY PENSION NOW, I HAVE BECAUSE MY SISTER PAID FOR IT!! That is the simple truth. She used to tell me, "You should have never gotten married to that guy. He was always sick." And I would reply, "So what? If he is sick, so be it. I CHOSE HIM and I LIKED HIM!"

The lyrics of the copla "A tu vera/by your side" encapsulates the filial love Luz felt for Maruja:

a tu vera, siempre a la verita tuya,/ by your side/ always by your side siempre a la verita tuya,/ always by your side hasta que de amor me muera./ Until love takes my life Ya pueden clavar puñales,/ They may stab me with daggers ya pueden cruzar tijeras,/ they might cross scissors ya pueden cubrir con sal,/ they might cover with salt los ladrillos de tu puerta./ the bricks of your doorway Ayer, hoy, mañana y siempre/ Yesterday, today, tomorrow and forever eternamente a tu vera,/ eternally by your side eternamente a tu vera./ eternally by your side

Two women alone raising two boys, now men with college degrees. Two women the Regime mostly forgot. One a widow left to fend for herself and her two children, the other unmarried and childless whose role in life was to take care of others. What little joy they had in their life they manufactured in the small cracks of time when they were not working, taking care of others. 
